\title{
Az etopozid szervezeten belüli eloszlásában és metabolizmusában szerepet játszó epigenetikai hatások*
}

\author{
Kovács Erika Rozália PhD-hallgató ${ }^{1}$ \\ Tóth Sára dr. ${ }^{2}$ Erdélyi Dániel János dr. ${ }^{3}$ \\ Semmelweis Egyetem, Általános Orvostudományi Kar, ${ }^{1}$ Klinikai Orvostudományok Doktori Iskola, \\ ${ }^{2}$ Genetikai, Sejt- és Immunbiológiai Intézet, ${ }^{3}$ II. Gyermekgyógyászati Klinika, Budapest
}

\begin{abstract}
Az etopozid egy topoizomeráz-II-gátló daganatellenes kemoterápiás szer, amelyet széles körben használnak hematológiai malignitások és szolid tumorok kezelésére. Terápiás indexe magas, használata számos rövid és hosszú távú mellékhatáshoz vezet, amelyek csökkentik a betegek gyógyulási esélyét. Dozírozása testfelület-alapú számítással történik, személyre szabott terápiás ajánlás jelenleg nincs. A gyógyszer biotranszformációjában és szállításában számos enzim és transzporter vesz részt; az etopozid farmakogenetikájáról is rendelkezünk ismeretekkel. Napjainkban előtérbe kerültek a farmakoepigenetikai kutatások is, ezért a szerzók betekintést kívánnak nyújtani az etopozid-útvonalat érintő epigenetikai változások kutatásába, kiemelve azokat a tanulmányokat, amelyek az enzimekre és a transzporterekre fókuszáltak. A jövőben az etopozid-útvonal epigenetikai változásai vélhetően fontos szerepet tölthetnek be a diagnosztikában, a prognosztikában és a személyre szabott terápiában.
\end{abstract}

Orv Hetil. 2018; 159(32): 1295-1302.

Kulcsszavak: etopozid, etopozid-útvonal, gyógyszer-metabolizmus, epigenetika, farmakoepigenetika

\section{Epigenetic effects affecting etoposide distribution and metabolism in the human body}

\begin{abstract}
Etoposide is a topoisomerase II inhibitor antitumor agent which is widely used in the treatment of several hematologic malignancies and solid tumors. The therapeutic index of etoposide is quite high, thus its application causes several short-term and long-term side effects which can decrease the chance to cure patients. Drug dosing is based on body surface area calculation; recommendations for individual dosing do not exist yet. The biotransformation and transportation of etoposide are carried out by enzymes and transporters as reported in pharmacogenomic studies published in this area. Nowadays pharmacoepigenetics research has come to the fore. The authors wish to give an insight into the research of the epigenetical changes of the etoposide pathways, especially focusing on published findings on enzymes and transporters with pharmacokinetic relevance. In the future, epigenetical changes of the etoposide pathway might have a great role in diagnostics, prognostics and personalized medicine.
\end{abstract}

Keywords: etoposide, etoposide pathway, drug metabolism, epigenetics, pharmacoepigenetics

Kovács ER, Tóth S, Erdélyi DJ. [Epigenetic effects affecting etoposide distribution and metabolism in the human body]. Orv Hetil. 2018; 159(32): 1295-1302.

(Beérkezett: 2018. április 15.; elfogadva: 2018. május 3.)

*A Dr. Fehér János Alapítvány 2018. évi pályázatán díjazott dolgozat. 


\section{Rövidítések}

$\mathrm{ABC}$-transzporter $=(\mathrm{ATP}$-binding casette transporter $) \mathrm{ATP}$ kötő kazetta transzporter; ALL = akut lymphoid leukaemia; $\mathrm{AML}=$ akut myeloid leukaemia; ATP = adenozin-trifoszfát; $\mathrm{BEP}=$ bleomicin-etopozid-ciszplatin CFTR $=($ cystic fibrosis transmembrane conductance regulator) cystás fibrosis transzmembrán konduktancia regulátor; $\mathrm{CpG}=$ (cytosine-phosphate-guanine) citozin-foszfát-guanin; $\mathrm{CYP}=$ (cytochrome P450) citokróm P450; DDR $=($ DNA damage response $)$ DNSkárosodás-válaszreakció; $\mathrm{DNMT}=(\mathrm{DNA}$ methyltransferase $)$ DNS-metiltranszferáz; DNS = dezoxiribonukleinsav; FDA = (Food and Drug Administration) az Egyesült Államok Élelmiszer- és Gyógyszer-engedélyeztetési Hivatala; GST = (glutathione-S-transferase) glutation-S-transzferáz; H69AR = multidrogrezisztens kissejtes tüdőcarcinoma sejtvonal; H69VP = etopozidrezisztens kissejtes tüdőcarcinoma sejtvonal; HAT = hiszton-acetiltranszferáz enzim; HDAC = hiszton-deacetiláz enzim; HepG2 = humán hepatocellularis carcinoma sejtvonal; HMT = hiszton-metiltranszferáz enzim; lncRNS = hosszú nem kódoló RNS; MCF-7 = humán emlóadenocarcinoma sejtvonal; MDR = multidrogrezisztencia $;$ MDRI = multidrogreziszten cia-asszociált fehérje-1; MEC = mitoxantron-etopozid-citarabin; miRNS = mikro-RNS; $\mathrm{MPO}=$ mieloperoxidáz $; \mathrm{mRNS}=$ (messenger RNS) hírvivő RNS; MRPI = (multidrug resistance-associated protein 1) multidrogrezisztencia-asszociált fehérje-1; ncRNS = nem kódoló RNS; NRII2 = (nuclear receptor subfamily 1 , group I, member 2) nukleáris receptor-1I2; P-gp = P-glikoprotein $;$ PTGS = prosztaglandin-szintáz $;$ PXR = pregnán X-receptor; RISC = RNS-indukált csendesítő komplex; RNS = ribonukleinsav; TET = TET-metil-citozin-dioxigenáz; TSA = trichostatin A; UGTIAl = uridin-difoszfát-glükuroniltranszferáz-1Al enzim; VDR = D-vitamin-receptor; VM-26 = tenipozid; VP-16 = etopozid

Az utóbbi évtizedben egyre inkább előtérbe kerülnek az epigenetikai témájú vizsgálatok az orvosi kutatásokban. $\mathrm{Az}$ etopozidról is rendelkezésre állnak már olyan farmakoepigenetikai témájú tanulmányok, amelyek az epigenetikai tényezők függvényében vizsgálják in vitro vagy in vivo a citosztatikus hatást vagy a mellékhatások kialakulását. A szerzők a jelen tanulmánnyal betekintést kívánnak nyújtani e kutatási területbe.

\section{Az etopozid citosztatikus hatása és mellékhatásai}

Az etopozid egy topoizomeráz-II-gátló, azon belül is a podofillotoxinok csoportjába tartozó citosztatikum. A podofillotoxinok természetben is előforduló vegyületek, amelyeket az Észak-Amerikában őshonos Berberidaceae családba tartozó Podophyllum peltatum, vagy más néven amerikai tojásbogyó gyökeréból és rhizomájából extraháltak [1]. A podofillotoxin félszintetikus származékai az etopozid (vagy VP-16) és a tenipozid (vagy VM-26), amelyeket a Sandoz gyógyszergyárban dolgozó Stähelin és von Wartburg vezetésével több mint 20 éves kutatómunka eredményeként állítottak elő [2].
Hatásmódját tekintve gátolja a replikáció során a DNS konformációját módosító, topoizomeráz-II-t. A topoizomeráz-II egy esszenciális enzim, melynek feladata az örökítőanyag topológiai állapotának módosítása azáltal, hogy a DNS-molekulához kötődve átmeneti kettősszáltöréseket indukál. Az etopozid a topoizomeráz-II-DNSkomplexhez kötődve gátolja a DNS-molekula törött végeinek ligálását, aminek következtében az enzimatikus folyamat megáll, és a DNS fragmentálódik [3, 4]. A DNS-szálak töréseinek kialakításában a szabadgyök-képződés is fontos szerepet játszik [5].

Az etopozidot széles körben alkalmazzák mind a gyermekkori, mind a felnőttkori malignitások kezelésére, mint például az ALL, az osteosarcoma, a Ewing-sarcoma, a neuroblastoma, a Wilms-tumor, az emlődaganat, a petefészekrák, a prostatarák és kiemelten a hererákok, valamint a kissejtes tüdőrák esetében [6].

Rövid távú mellékhatásaiként megemlíthető az alopecia, az emetogenitás, a mucositis, a myelotoxicitas, a hepatotoxicitas, az allergiás és anafilaxiás reakciók, a neuropathia, az arrhythmia és a cholestasis is. Hosszú távon másodlagos malignitások kialakulása figyelhető meg, amelyekért Kagan és mtsai feltételezései szerint a szabad gyökös reakciók is felelősek lehetnek [7].

A gyógyszer alkalmazásakor férfiak esetében a spermiumok számának ideiglenes csökkenése is megfigyelhető, ami más kemoterápiás szerekkel alkalmazva azoospermia kialakulásához is vezethet $[8,9]$.

Terápiás indexe magas, aminek következtében a betegek csak jelentős mellékhatások árán juthatnak a gyógyulás esélyéhez.

Az etopozid dozírozása testfelület-alapú számítással történik; jelenleg nem található személyre szabott dozírozási ajánlás sem a szakirodalomban, sem a klinikumban.

\section{Az etopozid cellularis eloszlásában és metabolizmusában szerepet játszó útvonalak}

Yang és mtsai 2009-ben az addig megjelent szakirodalom alapján közzétették az etopozid eloszlásában és metabolizmusában szerepet játszó útvonal (a továbbiakban etopozid-útvonal) részletes leírását.

Az etopozid metabolizmusában a májban található, a citokróm P450 (CYP) szupercsaládba tartozó CYP3A4 és CYP3A5 izoenzimek vesznek részt, amelyek génjeinek transzkripciós szabályozásáért a D-vitamin-receptor (VDR) és a pregnán X-receptor (NRII2/PXR) a felelós. Az NRII2 aktivitását moduláló xenobiotikumok - mint például a dexametazon és a rifampicin - növelik az etopozidclearence-t. A CYP3A4 és CYP3A5 izoenzimek Odemetiláció révén katechol- és kinon-metabolitokká alakítják az etopozidot. Ez a folyamat prosztaglandin-szintáz (PTGS) vagy mieloperoxidáz (MPO) enzimekkel is katalizálható. 
Az anyavegyület és a metabolit inaktiválása glutationés glükuronidkonjugáció révén történik, amely folyamatokban a glutation-S-transzferázok (GST) közé tartozó GSTT1/GSTP1, továbbá az UGT1Al (uridindifoszfát-glükuronil-transzferáz-1Al) enzimek vesznek részt.

$\mathrm{Az}$ etopozid konjugált és nem konjugált formáinak transzportjáért az ATP-kötő kazetta transzporter (ABC) szupercsaládba tartozó ABCBl (korábbi nevein MDRl vagy $\mathrm{Pgp}$ ), $\mathrm{ABCCl}$ (más néven $\mathrm{MRPl}$ ) és $\mathrm{ABCC} 3$ (más néven MRP3 vagy CFTR) transzporterek a felelősek. E transzporterek múködése következtében úgynevezett multidrogrezisztencia (MDR) is kialakulhat [10].

Sok más onkofarmakonéhoz hasonlóan a májban végbemenő gyógyszer-metabolizmus első lépésében az etopozid a CYP izoenzimek által oxidálódik (I. fázis), majd glükuronid- és glutationszármazék képződik (II. fázis). Végül az így keletkezett vízoldékony vegyület a vesén keresztül ürül ki a szervezetból (1. ábra).

\section{Az etopozid-útvonal epigenetikai szabályozásában fontos hatások}

Epigenetikai szabályozáson azokat az öröklődő változásokat értjük, amelyek a genomot érintik, de nem változtatják meg a DNS szekvenciáját.
A malignitások kialakulásában a kromoszómaaberrációkon és a mutációkon kívül az epigenetikai hatások is szerepet játszanak. Az utóbbi néhány évben derült fény arra, hogy az epigenetikai szabályozó gének mutációi is gyakoriak a humán tumorsejtekben [11].

A daganatok kialakítása mellett az etopozid-útvonalat szabályozó epigenetikai módosítások befolyásolhatják a gyógyszer hatását és mellékhatásainak kialakulását is. Ezek az epigenetikai hatások többfélék lehetnek, az etopozid-útvonal szempontjából fontosabbaknak a csoportosítása az alábbiakban olvasható.

\section{Transzkripciós mechanizmusok}

\section{DNS-metiláció}

A DNS-metiláció során jellemzően a CpG-dinukleotidokban a DNS 5 ' végén lévő citozin-pirimidin gyưrühöz egy metilcsoport kapcsolódik. Ezt a folyamatot a DNSmetiltranszferázok (DNMT) végzik, amelyeknek 3 fajtáját különböztetjük meg: a fenntartó metiltranszferázokat, vagyis a DNMTl-et és a de novo metiltranszferázok közé tartozó DNMT3A-t és DNMT3B-t.

A DNS-metiláció fontos szerepet játszik a gének szabályozásában, az X-kromoszóma inaktivációjában és a genomiális imprintingben is [12].

A DNS-demetiláció két átfedő mechanizmus révén történhet, és a metilációval együtt epigenetikai szabályo-

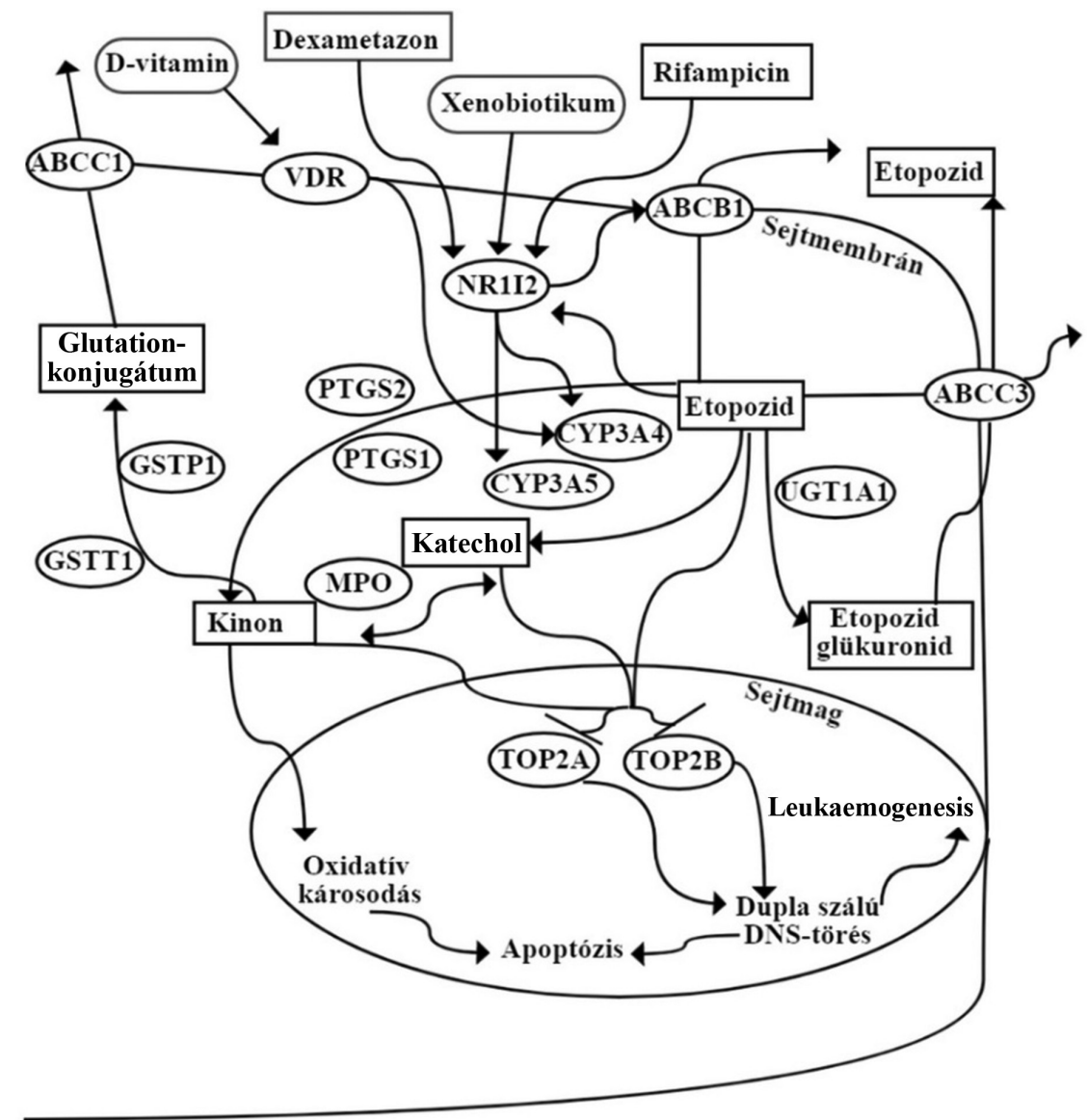


zó szereppel bír. A sejtosztódás során az 5-metil-citozin $(5 \mathrm{mC})$ elveszhet vagy törlődhet, ha a DNMT-ok hiányoznak vagy nem múködnek. Ezt a folyamatot passzív demetilációnak nevezik. Az aktív demetiláció a TET-metil-citozin-dioxigenáz (TET) enzimek segítségével történik [13].

A CpG-szigetek metilációs mintázata a daganat különböző fejlődési stádiumaiban is eltérő lehet. Erre példaként megemlíthető AML-ben a DNMT3A által mediált CpG-sziget metilációs mintázatának változása. Spencer és mtsai megfigyelései szerint a tumoriniciációban a CpGsziget hipometilációját, míg a tumorprogresszióban hipermetilációt tapasztaltak [14].

A DNS-metiltranszferáz inhibitorok leukaemiában érzékenyíteni tudják a sejteket a kemoterápiára. Ezért az FDA által engedélyezett szerek közül a decitabinnal kapcsolatban már ismert olyan fázis I és II vizsgálat eredménye, amelyek során tesztelték, hogy a MEC (mitoxantron-etopozid-citarabin) kezelés előtt decitabint alkalmazva ez a kezelési mód hatásosabbnak bizonyulhat-e a jelenleg alkalmazott kezelési protokollal szemben [15].

Egy másik tanulmány szerint in vitro körülmények között a DNMTl gátlására használt 5-azacitidint etopoziddal együtt alkalmazva a gyógyszer-koncentrációtól függő szinergista hatást tapasztaltak, ezért vélhetően együttes alkalmazásuk javíthatja az etopozid hatását az AML és a nem kissejtes tüdőrák kezelésében [16].

\section{Poszttranszkripciós mechanizmusok}

\section{Nem kódoló RNS-ek (ncRNS)}

Rövid nem kódoló RNS-ek, mikro-RNS-ek (miRNS)

A miRNS-ek 18-25 nukleotidból álló rövid, nem kódoló RNS-molekulák. Biogenezisüket tekintve a transzkripció első lépésében az RNS-polimeráz néhány száz nukleotid nagyságú, hajtú struktúrájú molekulát, úgynevezett primiRNS-t készít. A pri-miRNS a mRNS-hez hasonlóan 5' sapkával és 3' poli-A (poli-adenozin)-farokkal rendelkezik. A következő lépésben a sejtmagban a pri-miRNS-t egy RNáz-III típusú enzim, a Drosha hasítja, amely folyamat eredményeképpen 70-100 nukleotid hosszúságú, hajtü alakú, úgynevezett pre-miRNS keletkezik. Ez a pre-miRNS a citoplazmába exportálódik az exportin-5 nevű Ran-GTP-dependens dsRNS-kötő fehérje segítségével. A citoplazmában a szintén RNáz-III típusú Dicer nevú enzim hasítja tovább 22 nukleotid hosszúságú darabokra, s ezáltal kialakul az érett miRNS. A dupla szálú miRNS egy ATP-függő folyamatban az RNS-indukált csendesítő komplexben (RISC) egyszálúvá bomlik. Végül ez az egyszálú miRNS a komplementaritás szabályainak megfelelően egy mRNS-hez kötődve poszttranszkripciós gátlást fejt ki [17, 18].

A miRNS-ek számos biológiai folyamatban vesznek részt. Fontos szerepük van az embriogenezisben, a sejtdifferenciációban, a proliferációban, az apoptózisban, és szerepet játszanak a betegségek kialakulásában, azok kö- zül is leginkább a tumorgenezisben és a daganatok progressziójában [19]. Továbbá befolyásolhatják a daganatkemoterápiában alkalmazott gyógyszerek hatását is. Az etopozid vonatkozásában például Kollinerová és mtsai in vitro vizsgálataik során azt tapasztalták, hogy HeLa-sejtekben a miR-29b expressziójának növekedése fokozza az etopozidtoxicitást [20].

\section{Hosszú nem kódoló RNS-ek (lncR NS)}

A hosszú nem kódoló RNS-ek (lncRNS) mérete 200 bázistól 100 kilobázisig terjedhet. Az újonnan felismert lncRNS-ek mellett a legismertebb képviselőik közé tartoznak a riboszomális RNS-ek. Számos biológiai folyamat szabályozásában vesznek részt, mint például a hisztonmodifikációban, a kromatinremodellezésben és a génexpresszió szabályozásában.

A lncRNS-ek egyik legismertebb tagja a XIST, amely az X-kromoszóma-inaktivációban játszik fontos szerepet, de számos olyan lncRNS is ismert, amely a daganatok kialakulásával hozható összefüggésbe (például H19, HOTAIR, MALATI) [21].

Az etopozid tekintetében a lncRNS-ek közül megemlíthető a DDSRl, amely többek között etopozidkezelés hatására indukálódik, és a p53 tumorszuppresszor szabályozása alatt állva fontos szerepet tölt be a genomstabilitás fenntartásában [22].

Mind a rövid, mind pedig a hosszú nem kódoló RNSek szállításában részt vesznek az extracellularis vesiculák, amelyekról megfigyelték, hogy az egészséges kontrollcsoportokhoz képest az egyes daganatos kórképekben a szérumban mérhető mennyiségük megnövekedett, ezért a jövơben várhatóan több kórképben, köztük a hematológiai malignitásokban is potenciális biomarkerek lehetnek [23]. Ezek az extracellularis vesiculák vélhetően az etopozid hatását befolyásoló nem kódoló RNS-ek szállításában is részt vehetnek, ezért a farmakoepigenetikai kutatások egyik lehetséges célpontjává válhatnak a későbbiekben.

\section{Poszttranszlációs mechanizmus}

\section{Hisztonmodifikáció}

A hisztonmodifikációban is úgynevezett epigenetikai írófehérjék vesznek részt, amelyek a meghatározott doméneket felismerni képes epigenetikai olvasófehérjék segítségével befolyásolják a kromoszómaremodellinget, amely szabályozza a kromoszómához való hozzáférést és ezen keresztül a transzkripciót is. A hisztonmódosítások közé tartozik többek között a hisztonacetiláció, -metiláció és -foszforiláció, amelyek fontos szerepet játszanak a génexpresszió szabályozásában a transzkripció aktiválása vagy represszálása révén. Az egyik legfontosabb epigenetikai módosítás a H3 hiszton acetilációja, amely a transzkripció aktiválásával áll kapcsolatban. A hiszton-acetiltranszferázokat (HAT) transzkripciós koaktivátorokként, a hiszton-deacetilázokat (HDAC) pedig transzkripciós korepresszorokként identifikálták [24]. 
Az acetiláció mellett fontos megemlíteni a metilációt is, amely a hiszton-metiltranszferáz (HMT) enzimek segítségével megy végbe, és attól függően, hogy melyik lizinresiduum metilálódik, különböző hatásai lehetnek a génexpresszióra. A gén transzkripciójának aktiválása elsősorban a transzkripciós starthely közelében lévő módosított H3K4me2/3 jelenlétének köszönhető [25, 26].

A hisztonmodifikációban fontos szerepet játszó fehérjék génjében bekövetkező változások is hozzájárulhatnak a gyógyszer-rezisztencia kialakulásához. Az etopozid vonatkozásában erre nagyon jó példák a DNS-károsodás-válaszreakcióban (DDR) szerepet játszó H3K36me3-transzferázt kódoló SETD2-génben bekövetkező mutációk, amelyek leukaemiában etopozidrezisztenciához vezetnek [27]. A hiszton és nem hiszton fehérjék argininmetilációját katalizáló, a PRMT7-gén által kódolt arginin-metiltranszferáz enzim több tanulmány szerint részt vesz a DDR szabályozásában, szerepet játszik a férficsíravonal-imprintált gének metilációjában, és downregulációja befolyásolja a sejtek etopozidra és más DNSkárosító ágensekre való érzékenységét [28, 29].

Egy másik in vitro tanulmányban a H3K36me3 és a H4Kl6ac epigenetikai módosítások közötti kapcsolatot vizsgálták a DNS-kettősszál-törések indukciójában. Li és Wang leírták, hogy etopozidkezelés hatására emelkedik a H3K36me3 és a H4Kl6ac mennyisége, valamint egy új útvonalat is bemutattak, amely szerint a $\mathrm{H} 3$ hisztonvariáns 36. pozícióban lévő lizinjének a trimetilációja stimulálja a H4 hisztonvariáns 16. pozícióban lévő lizinjének acetilációját, és ezáltal DNS-kettősszál-törések indukciója figyelhető meg a humán sejtekben [30].

Egy 2016. évi tanulmány szerint a csírasejtes heretumorok kezelésére használt BEP- (bleomicin-etopozidciszplatin) kemoterápia hatással lehet a kromatinremodellingre is. Hím patkányok vizsgálatakor kimutatták, hogy a BEP-kezelés hatására a spermatogenezis során megváltoznak az epigenetikai jelek, amelyek lazább kromatinstruktúrához és bizonyos gének transzkripciójához vezetnek. Ez a kevésbé kompakt spermiumkromatin a megváltozott epigenetikai jelekkel valószínúleg hozzájárul a termékenység csökkenéséhez [31].

A hisztonmodifikációk reverzibilisek, ezért számos olyan vegyületet teszteltek preklinikai vagy klinikai vizsgálatokban, amelyek az epigenetikai enzimeket és szabályozó fehérjéket célozzák meg, és vélhetően hatékonynak bizonyulhatnak a malignitás korlátozásában [32].

A H3K27me3 epigenetikai jel kialakításáért felelős EZH2 hiszton-metiltranszferáz fontos szerepet játszik többek között az apoptózis folyamatában is. Túlexpreszszálása számos tumortípusban megfigyelhető. 2016-ban Smonskey és mtsai leírták, hogy az EZH2 gátlásával a multidrogrezisztens B-sejt-eredetű lymphoma esetében újra lehet érzékenyíteni a sejteket az etopozid mediálta apoptózisra [33].

\section{A CYP3A4 és CYP3A5 izoenzimek epigenetikai szabályozása}

A CYP3A4 és CYP3A5 enzimek számos gyógyszer metabolizmusában vesznek részt, ezért már régről ismert, hogy ezeknek az enzimeknek a génpolimorfizmusai befolyásolhatják a gyógyszerek hatását és a mellékhatások megjelenését.

A szakirodalom áttanulmányozása alapján elmondható, hogy a CYP3A4 enzim esetében, a farmakogenetikai vizsgálatokkal ellentétben, napjainkban a releváns farmakoepigenetikai hatások jóslása még leginkább in silico, bioinformatikai módszerekkel történik. Az egyik ilyen vizsgálat alapján 105 olyan miRNS-t találtak, amely hatással lehet a CYP3A4-expresszióra [34, 35].

E vizsgálati eredmények mellett néhány in vitro kutatás eredménye is rendelkezésre áll. Ilyen vizsgálat során mutatták ki, hogy a CYP3A4 enzimekben a CpG-szigetek metilációs mintázata eltérő a felnőtt- és az újszülöttmájban, ezért valószínúleg a metilezési státusz is hozzájárulhat a CYP3A4-enzim-aktivitás különbségéhez a felnőtt egyéneknél [36].

A transzkripciós mechanizmusok HepG2-sejteken történő vizsgálatakor megállapították azt is, hogy a DNMT-inhibitorok, mint például a decitabin (5-aza-2' dezoxicitidin), hatással vannak a CYP3A4 és CYP3A5 enzimek expressziójára is, ezért a jövőben érdemes lehet vizsgálni ezeknek a CYP enzimeknek az esetében a szubsztrátjaik és a DNMT-inhibitorok között létrejövő esetleges gyógyszer-interakciót is [37].

Fontos megemlíteni, hogy a különböző miRNS-ek indirekt módon is szabályozhatják a CYP enzimeket azáltal, hogy az őket befolyásoló pregnán X- vagy D-vitamin-receptorra fejtik ki hatásukat.

A pregnán X (NRII2/PXR) transzkripciós faktor számos gyógyszer-metabolizáló enzim génjének az átírását képes szabályozni, így köztük az etopozid-útvonalon található CYP3A4 és CYP3A5 enzimek expresszióját is.

Közel egy évtizede ismert, hogy a pregnán X-receptor epigenetikai szabályozása összefüggésben áll a CYP3A4 génexpressziójával, amely ezáltal az enzim metabolizálóképességét is befolyásolja. HepG2-sejtvonalon végzett kísérletek során Takagi és mtsai kimutatták, hogy a miR148a az NR1I2-re hatva befolyásolta a CYP3A4 expreszszióját, mégpedig oly módon, hogy a miR-148a túlexpresszálása következtében az NRII2 protein szintje csökkent, és ez a csökkenés a CYP3A4 mRNS- és fehérjeszintjére is negatív hatással volt [38].

A másik hasonló példa a CYP3A4 indirekt módon történő enzimaktivitás-csökkentésére a D-vitamin-receptor (VDR) szabályozása a miR-27b által [39].

\section{Az etopozid metabolitjainak inaktiválásáért felelős enzimek epigenetikai szabályozása}

A GSTT1, GSTPl és UGT1Al enzimekről az etopozid vonatkozásában epigenetikai témájú publikáció jelenleg 
nem található a szakirodalomban. Számos publikáció azonban felhívja a figyelmet arra a farmakoepigenetikai eredményre, amely szerint Dluzen és mtsai in vitro körülmények között megállapították, hogy a miR-49l-3p expressziója hatással van az UGTlAl-génexpresszióra és ezáltal a mellrák kezelésében használt raloxifen hatására is [40].

Régóta ismert, hogy a GSTPl-gén promóter metilációja epigenetikai markerként szolgálhat a hólyagrák és a prostatarák esetében $[31,41]$.

Mindezek mellett a GSTPl-gén promóter régiójában található $\mathrm{CpG}$-szigetek metilációs mintázata olyan farmakoepigenetikai biomarkerként is szolgál, amely alapján megjósolható a rákos sejt válasza a doxorubicinkezelésre $[42,43]$.

\section{$\mathrm{Az}$ ABC-transzporterek epigenetikai regulációja}

\section{$A B C B I$}

Ho és mtsai array kísérletek során megfigyelték, hogy a leukaemiasejtek etopoziddal történő rövid távú expozícióját követően néhány nappal átmeneti gyógyszer-rezisztencia alakult ki. Megállapították, hogy ezt a jelenséget az ABCBl mRNS-expressziójának, valamint a miR-135b és miR-196b miRNS-ek szintjének átmeneti növekedése kíséri [44].

Ennek a transzporternek az esetében 2007-ben ElKhoury és kutatócsoportja a hisztonmódosításokat vizsgálva leírta, hogy ha az etopozidrezisztens H69VP kissejtes tüdőrák sejtvonalat hiszton-deacetiláz-gátló trichostatin A-val (TSA) kezelték, akkor a transzporter génexpressziójának mind mRNS-, mind fehérjeszinten való gátlását tapasztalták. Ezzel eredményeik alátámasztották azt az elképzelést, hogy a HDAC-inhibitorok modulálhatják a multidrogrezisztenciát az ABC-transzporterek gátlásán keresztül [45].

Baker és mtsai kísérleteik során megállapították, hogy az etopozid és a daunorubicin kemoterápiás szerek aktiválják az $\mathrm{ABCB} 1$ transzkripcióját, ha annak promótere hipometilált. Megfigyelték, hogy a gyógyszerindukált ABCBl-transzkripció-aktiváláshoz különböző hisztonmódosulások is társíthatók: a H3-hisztonacetiláció és a H3K4-metiláció tovább növelte az ABCBl-transzkripciót [46].

\section{$A B C C 1$}

Liang és mtsai az etopozidrezisztens humán emlőráksejtek (MCF-7/VP-16) vizsgálatakor azt találták, hogy abban, a nem rezisztens szülői MCF-7 sejtvonallal összehasonlítva, az ABCCl mRNS- és fehérjeoverexpressziója tapasztalható. Microarray vizsgálat során megállapították, hogy ennek az az oka, hogy az etopozidrezisztens sejtekben a miR-326 alulszabályozott. További vizsgálatok során miR-326-ot transzfektálva az MCF-7/VP-16 sejtvonalba az ABCCl-expresszió csökkent, és fokozódott a sejtek etopozid- és doxorubicinérzékenysége. A normálmellszövet, a metasztázis nélküli, korai stádiumú emlődaganat-szövet és a metasztázisos emlődaganatszövet vizsgálatakor folyamatosan csökkenő miR-32-expressziót tapasztaltak, ezzel ellenkezőleg pedig a késői stádiumú emlőrákszövet esetében magas ABCCl-expressziót figyeltek meg [47].

Guo és mtsai a multidrogrezisztencia-variáns H69AR kissejtes tüdőcarcinoma sejtvonal vizsgálata során megállapították, hogy a miR-134-mimetikum hatására az etopozidérzékenység fokozódik, az $\mathrm{ABCCl}$ protein szintje csökken, amely csökkenés nagymértékben korrelált a magasabb miR-134-szinttel [48].

Az etopozid-útvonalat és a gyógyszerhatást befolyásoló miRNS-eket az 1. táblázat tartalmazza.

\section{1. táblázat $\mid$ Az etopozid-útvonalat és a gyógyszerhatást befolyásoló miRNS-ek}

\begin{tabular}{lllll}
\hline & & miRNS & Hatás & Ref. \\
\hline Enzim & CYP3A4 & $\uparrow$ miR-27b & $\downarrow$ CYP3A4-expresszió & {$[38]$} \\
& & $\uparrow$ miR-148a & $\downarrow$ CYP3A4-expresszió & {$[39]$} \\
& UGTlAl & $\downarrow$ miR-491-3p & $\uparrow$ UGT1Al-expresszió & {$[40]$} \\
\hline $\begin{array}{l}\text { Transz- } \\
\text { porter }\end{array}$ & ABCBl & $\uparrow$ miR-135b & $\uparrow$ ABCB1-expresszió & {$[44]$} \\
& & $\uparrow$ miR-196b & $\uparrow$ ABCB1-expresszió & {$[44]$} \\
& ABCCl & $\downarrow$ miR-326 & $\uparrow$ ABCCl-expresszió & {$[47]$} \\
& & $\uparrow$ miR-134 & $\downarrow$ ABCCl-expresszió & {$[48]$} \\
\hline
\end{tabular}

\section{Következtetések}

Az etopozidfarmakogenetika szakirodalma igen szúkös, ehhez hasonlóan az etopozidfarmakoepigenetikai témájú tanulmányokból is igen kevés található meg a hazai és a nemzetközi szakirodalomban. Ezek mellett rendelkezésünkre állnak olyan - fóleg in vitro - tanulmányok, amelyek az etopozid-útvonalon lévő enzimeket és transzportereket szabályozó epigenetikai hatásokkal foglalkoznak, ami annak is köszönhető, hogy ezek a gyógyszermetabolizmusban és -transzportban részt vevő fehérjék más gyógyszerek biotranszformációjában és transzportálásában is részt vesznek. Ezért érdemes ezeknek a tanulmányoknak az eredményeire is figyelmet fordítani. Az eddigi eredmények azt sugallják, hogy az etopozid farmakoepigenetikai vonatkozásait valószínúleg a jövóben a gyógyszerrezisztens állapot kimutatásában, az egyes betegségek prognózisának meghatározásában, továbbá a személyre szabott medicinában és a gyógyszerkutatásban lehet majd hasznosítani. 
Anyagi támogatás: A közlemény megírása anyagi támogatásban nem részesült.

Szerzôi munkamegosztás: K. E. R.: A szakirodalom kutatása, elemzése, az összefoglaló dolgozat megírása, szerkesztése, ábra és táblázat készítése. E. D. J.: A kutatás irányítása, szakértői feladat ellátása, stilisztikai munkák elvégzése. T. S.: Szakértői feladat ellátása. A cikk végleges változatát mindhárom szerző elolvasta és jóváhagyta.

Érdekeltségek: A szerzőknek nincsenek érdekeltségeik.

\section{Irodalom}

[1] Imbert TF. Discovery of podophyllotoxins. Biochimie 1998; 80: 207-222.

[2] Stähelin HF, von Wartburg A. The chemical and biological route from podophyllotoxin glucoside to etoposide: ninth Cain memorial Award lecture. Cancer Res. 1991; 51: 5-15.

[3] Meresse P, Dechaux E, Monneret C, et al. Etoposide: discovery and medicinal chemistry. Curr Med Chem. 2004; 11: 24432466.

[4] Montecucco A, Zanetta F, Biamonti G. Molecular mechanisms of etoposide. EXCLI J. 2015; 14: 95-108.

[5] Mans DR, Lafleur MV, Westmijze EJ, et al. Formation of different reaction products with single- and double-stranded DNA by the ortho-quinone and the semi-quinone free radical of etoposide (VP-16-213). Biochem Pharmacol. 1991; 42: 2131-2139.

[6] DrugBank database 5.0. Etoposide. Available from: https:// www.drugbank.ca/drugs/DB00773 [accessed: January 4, 2018].

[7] Kagan VE, Yalowich JC, Borisenko GG, et al. Mechanism-based chemopreventive strategies against etoposide-induced acute myeloid leukemia: free radical/antioxidant approach. Mol Pharmacol. 1999; 56: 494-506.

[8] Ezoe S. Secondary leukemia associated with the anti-cancer agent, etoposide, a topoisomerase II inhibitor. Int J Environ Res Public Health 2012; 9: 2444-2453.

[9] Meistrich ML. Male gonadal toxicity. Pediatr Blood Cancer 2009; 53: 261-266

[10] Yang J, Bogni A, Schuetz EG, et al. Etoposide pathway. Pharmacogenet Genomics 2009; 19: 552-553.

[11] Pfister SX, Ashworth A. Marked for death: targeting epigenetic changes in cancer. Nat Rev Drug Discov. 2017; 16: 241-263.

[12] Bird A. DNA methylation patterns and epigenetic memory. Genes Dev. 2002; 16: 6-21.

[13] Fitcz G. New insights into mechanisms that regulate DNA methylation patterning. J Exp Biol. 2015; 218: 14-20.

[14] Spencer DH, Russler-Germain DA, Ketkar S, et al. CpG island hypermethylation mediated by DNMT3A is a consequence of AML progression. Cell 2017; 168: 801-816.e13.

[15] Halpern AB, Othus M, Huebner EM, et al. Mitoxantrone, etoposide and cytarabine following epigenetic priming with decitabine in adults with relapsed/refractory acute myeloid leukemia or other high-grade myeloid neoplasms: a phase $1 / 2$ study. Leukemia 2017; 31: 2560-2567.

[16] Füller M, Klein M, Schmidt E, et al. 5-Azacytidine enhances efficacy of multiple chemotherapy drugs in AML and lung cancer with modulation of $\mathrm{CpG}$ methylation. Int J Oncol. 2015; 46: 1192-1204.

[17] Romero-Cordoba SL， Salido-Guadarrama I， RodriguezDorantes M, et al. miRNA biogenesis: biological impact in the development of cancer. Cancer Biol Ther. 2014; 15: 1444-1455.

[18] Rácz Z, Kaucsár T, Hamar P. The huge world of small RNAs: regulating networks of microRNAs (review). Acta Physiol Hung. 2011; 98: 243-251.
[19] Dong H, Lei J, Ding L. MicroRNA: function, detection, and bioanalysis. Chem Rev. 2013; 113: 6207-6233.

[20] Kollinerová S, Dostál Z, Modrianský M. MicroRNA hsa-miR$29 \mathrm{~b}$ potentiates etoposide toxicity in HeLa cells via down-regulation of Mcl-1. Toxicol In Vitro 2017; 40: 289-296.

[21] Nagy Z, Szabó DR, Zsippai A, et al. Relevance of long noncoding RNAs in tumour biology. [A hosszú, nem kódoló RNS ek jelentősége a daganatbiológiában.] Orv Hetil. 2012; 153: 1494-1501. [Hungarian]

[22] Chaudhary R, Lal A. Long noncoding RNAs in the p53 network. Wiley Interdiscip Rev RNA 2017; 8: el410.

[23] Rzepiel A, Kutszegi N, Cs. Sági J, et al. Extracellular vesicles and their role in hematological malignancies. [Extracelluláris vesiculák és hematológiai malignitásokban játszott szerepük.] Orv Hetil. 2016; 157: 1379-1384. [Hungarian]

[24] Wang Z, Zang C, Cui K, et al. Genome-wide mapping of HATs and HDACs reveals distinct functions in active and inactive genes. Cell 2009; 138: 1019-1031.

[25] Barski A, Cuddapah S, Cui K, et al. High-resolution profiling of histone methylations in the human genome. Cell 2007; 129: 823-837.

[26] Guenther MG, Levine SS, Boyer LA, et al. A chromatin landmark and transcription initiation at most promoters in human cells. Cell 2007; 130: 77-88.

[27] Mar BG, Chu SH, Kahn JD, et al. SETD2 alterations impair DNA damage recognition and lead to resistance to chemotherapy in leukemia. Blood 2017; 130: 2631-2641.

[28] Jelinic P, Stehle JC, Shaw P. The testis-specific factor CTCFL cooperates with the protein methyltransferase PRMT7 in H19 imprinting control region methylation. PLoS Biol. 2006; 4: e355.

[29] Bleibel WK, Duan S, Huang RS, et al. Identification of genomic regions contributing to etoposide-induced cytotoxicity. Hum Genet. 2009; 125: 173-180.

[30] Li L, Wang Y. Cross-talk between the H3K36me3 and H4Kl6ac histone epigenetic marks in DNA double-strand break repair. J Biol Chem. 2017; 292: 11951-11959.

[31] Bagheri-Sereshki N, Hales BF, Robaire B. The effects of chemotherapeutic agents, bleomycin, etoposide, and cisplatin, on chromatin remodeling in male rat germ cells. Biol Reprod. 2016; 94 : 811-819.

[32] Graça I, Pereira-Silva E, Henrique R, et al. Epigenetic modulators as therapeutic targets in prostate cancer. Clin Epigenetics 2016; 8: 98.

[33] Smonskey M, Lasorsa E, Rosario S, et al. EZH2 inhibition resensitizes multidrug resistant B-cell lymphomas to etoposide mediated apoptosis. Oncoscience 2016; 3: 21-30.

[34] Han N, Song YK, Burckart GJ, et al. Regulation of pharmacogene expression by microRNA in The Cancer Genome Atlas (TCGA) Research Network. Biomol Ther (Seoul). 2017; 25: $482-489$.

[35] Wei Z, Jiang S, Zhang Y, et al. The effect of microRNAs in the regulation of human CYP3A4: a systematic study using a mathematical model. Sci Rep. 2014; 4: 4283.

[36] Kacevska M, Ivanov M, Wyss A, et al. DNA methylation dynamics in the hepatic CYP3A4 gene promoter. Biochimie 2012; 94: $2338-2344$.

[37] Dannenberg LO, Edenberg HJ. Epigenetics of gene expression in human hepatoma cells: expression profiling the response to inhibition of DNA methylation and histone deacetylation. BMC Genomics 2006; 7: 181.

[38] Takagi S, Nakajima M, Mohri T, et al. Post-transcriptional regulation of human pregnane $\mathrm{X}$ receptor by micro-RNA affects the expression of cytochrome P450 3A4. J Biol Chem. 2008; 283: 9674-9680.

[39] Pan YZ, Gao W, Yu AM. MicroRNAs regulate CYP3A4 expression via direct and indirect targeting. Drug Metab Dispos. 2009; 37: 2112-2117. 
[40] Dluzen DF, Sun D, Salzberg AC, et al. Regulation of UDP-glucuronosyltransferase $1 \mathrm{Al}$ expression and activity by microRNA 491-3p. J Pharmacol Exp Ther. 2014; 348: 465-477.

[41] Kim WJ, Kim YJ. Epigenetic markers for bladder cancer in urine. Transl Oncogenomics 2007; 2: 35-42.

[42] Dejeux E, Rønneberg JA, Solvang H, et al. DNA methylation profiling in doxorubicin treated primary locally advanced breast tumours identifies novel genes associated with survival and treatment response. Mol Cancer 2010; 9: 68.

[43] Heyn H, Esteller M. DNA methylation profiling in the clinic: applications and challenges. Nat Rev Genet. 2012; 13: 679-692.

[44] Ho TT, He X, Mo YY, et al. Transient resistance to DNA damaging agents is associated with expression of microRNAs- $135 \mathrm{~b}$ and $-196 \mathrm{~b}$ in human leukemia cell lines. Int J Biochem Mol Biol. 2016; 7: 27-47.

[45] El-Khoury V, Breuzard G, Fourré N, et al. The histone deacetylase inhibitor trichostatin A downregulates human MDRI $(A B C B 1)$ gene expression by a transcription-dependent mecha- nism in a drug-resistant small cell lung carcinoma cell line model. Br J Cancer 2007; 97: 562-573.

[46] Baker EK, Johnstone RW, Zalcberg JR, et al. Epigenetic changes to the MDRl locus in response to chemotherapeutic drugs. Oncogene 2005; 24: 8061-8075.

[47] Liang $\mathrm{Z}$, Wu H, Xia J, et al. Involvement of miR-326 in chemotherapy resistance of breast cancer through modulating expression of multidrug resistance-associated protein 1. Biochem Pharmacol. 2010; 79: 817-824.

[48] Guo L, Liu Y, Bai Y, et al. Gene expression profiling of drug-resistant small cell lung cancer cells by combining microRNA and cDNA expression analysis. Eur J Cancer 2010; 46: 1692-1702.

(Erdélyi Dániel János dr., Budapest, Túzoltó u. 7-9., 1094 e-mail: erdelyi.daniel@med.semmelweis-univ.hu)

\section{NOTA \\ Új fejlesztés az egészségügyben dolgozók, tanulók részére!}

A magyar nyelvử szakirodalmi keresőszolgáltatás

\section{MI a NOTA?}

Napivizit Orvosi Tudástár Alkalmazás

\section{Mit tud a NOTA portál?}

Megkönnyíti a magyar nyelvú

Eszköztöl függetlenül, akár okostelefonról, a betegágy mellett állva is használható. szakirodalmi források keresését.

\section{Miben kereshet a NOTA-val?}

Az Akadémiai Kiadó folyóirataiban: Orvosi Hetilap, Magyar Sebészet, Mentálhigiéné és Pszichoszomatika.

Más kiadók magyar nyelvũ szakfolyóirataiban: pl. Lege Artis Ideggyógyászati Szemle.

A hatályos szakmai irányelvekben.

Magyar nyelvű kérdésekre adott angol nyelvű találatokban, a PubMeden. Medicinae, Hypertonia és Nephrologia

\section{nota.hu}

Amennyiben további információra lenne szüksége, keressen minket elérhetőségeinken: journals@akademiai.hu /hirdetes@akademiai.hu

\section{西}
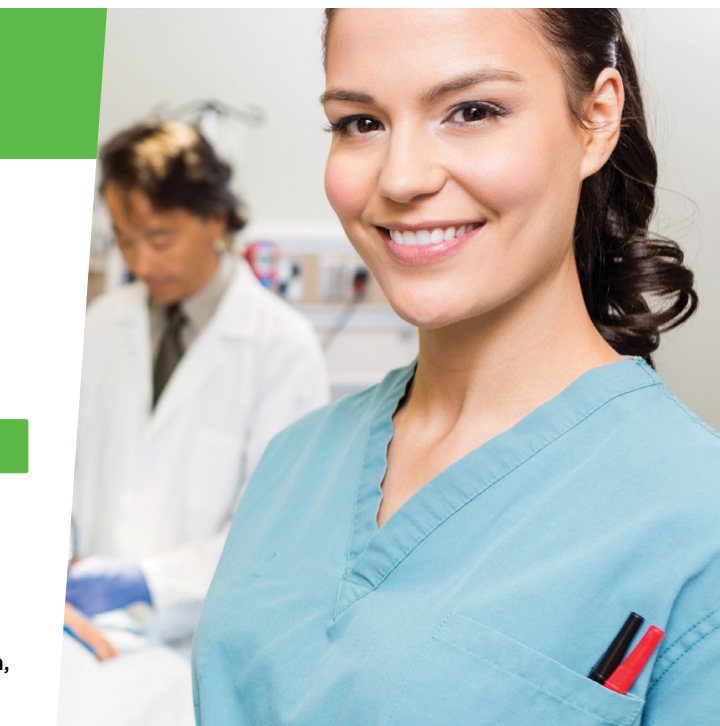

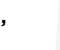

.

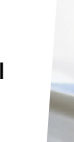

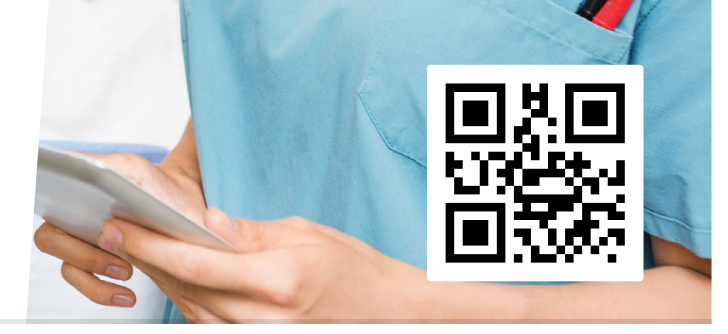

\section{Akadémiai Kiadó}

A Wolters Kluwer Csoport tagja

1117 Budapest, Prielle Kornélia u. 21-35. / Telefon: (1) 464-8246

www.akademiai.hu / www.akademiai.com

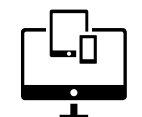

INOTA

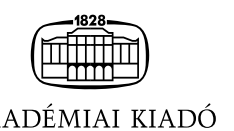

AKADÉMIAI KIADÓ

A cikk a Creative Commons Attribution-NonCommercial 4.0 International License (https://creativecommons.org/licenses/by-nc/4.0) feltételei szerint publikált Open Access közlemény, melynek szellemében a cikk nem kereskedelmi célból bármilyen médiumban szabadon felhasználható, megosztható és újraközölhető, feltéve, hogy az eredeti szerző és a közlés helye, illetve a CC License linkje és az esetlegesen végrehajtott módosítások feltüntetésre kerülnek. 